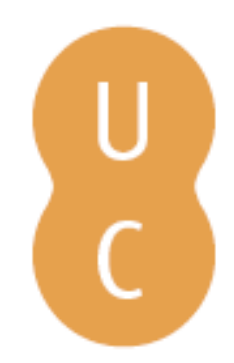

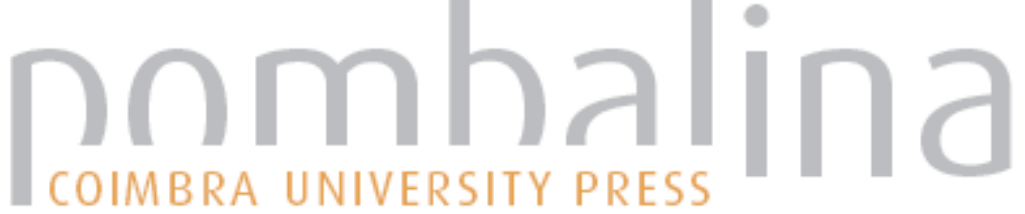

\section{Hose laying rates for forest firefighting in Greece}

Autor(es): $\quad$ Xanthopoulos, Gavriil; Kousaridas, loannis

Publicado por: Imprensa da Universidade de Coimbra

URL

persistente:

URI:http://hdl.handle.net/10316.2/34268

DOI:

DOI:http://dx.doi.org/10.14195/978-989-26-0884-6_155

Accessed : $\quad$ 26-Apr-2023 00:45:45

A navegação consulta e descarregamento dos títulos inseridos nas Bibliotecas Digitais UC Digitalis, UC Pombalina e UC Impactum, pressupõem a aceitação plena e sem reservas dos Termos e Condições de Uso destas Bibliotecas Digitais, disponíveis em https://digitalis.uc.pt/pt-pt/termos.

Conforme exposto nos referidos Termos e Condições de Uso, o descarregamento de títulos de acesso restrito requer uma licença válida de autorização devendo o utilizador aceder ao(s) documento(s) a partir de um endereço de IP da instituição detentora da supramencionada licença.

Ao utilizador é apenas permitido o descarregamento para uso pessoal, pelo que o emprego do(s) título(s) descarregado(s) para outro fim, designadamente comercial, carece de autorização do respetivo autor ou editor da obra.

Na medida em que todas as obras da UC Digitalis se encontram protegidas pelo Código do Direito de Autor e Direitos Conexos e demais legislação aplicável, toda a cópia, parcial ou total, deste documento, nos casos em que é legalmente admitida, deverá conter ou fazer-se acompanhar por este aviso. 


\section{ADVANCES IN}

Forest Fire

\section{RESEARCH}

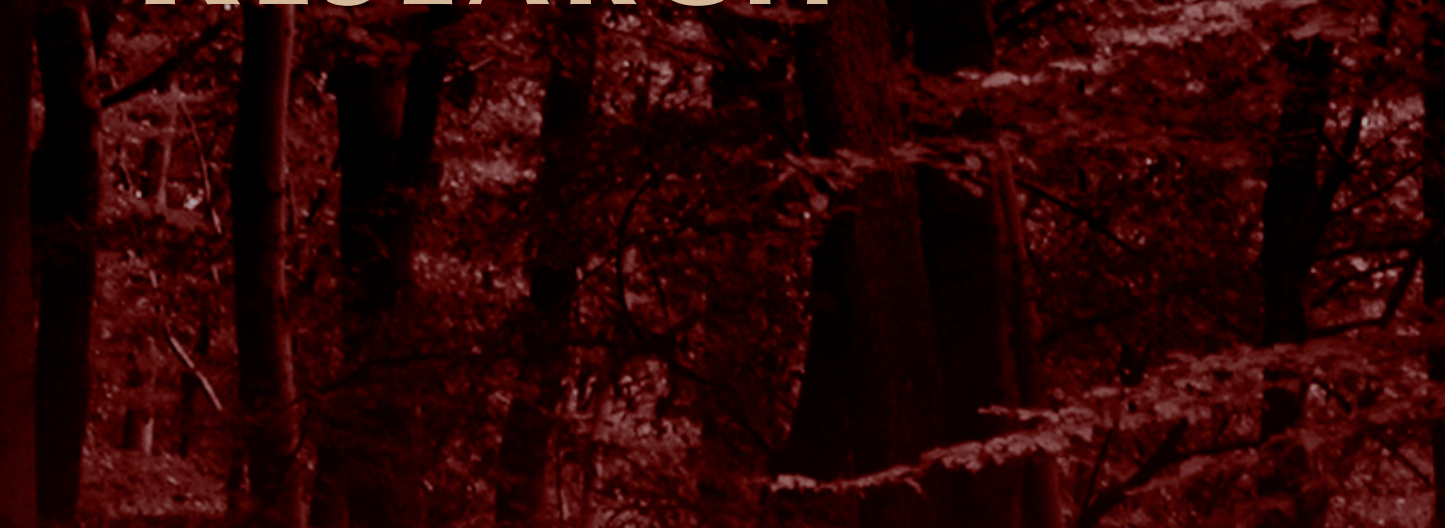

\section{DOMINGOS XAVIER VIEGAS}

\section{EDITOR}




\title{
Hose laying rates for forest firefighting in Greece
}

\author{
Gavriil Xanthopoulos ${ }^{\mathrm{a}}$, Ioannis Kousaridas ${ }^{\mathrm{b}}$ \\ ${ }^{a}$ Hellenic Agricultural Organization "Demeter". Institute of Mediterranean Forest Ecosystems and \\ Forest Products Technology.Terma Alkmanos, Ilisia, 11528, Athens, Greece.gxnrtc@fria.gr \\ ${ }^{b}$ Ministry of Public Order and Citizen Protection. Fire Service Headquarters. 4 Mourouzi street, \\ Kolonaki, 10674, Athens, Greece.kousjo@gmail.com
}

\begin{abstract}
Knowledge and models of firefighting are of great importance for decisions on presuppression planning, dispatching of firefighting forces and operational planning of fire suppression. Significant research effort has been devoted to built such knowledge so far. However, all such information has to be interpreted carefully because it can be affected by various local factors. One example of missing information in regard to firefighting performance is the rate of hose laying by ground forces trying to reach and follow the head or flanks of a fire. Such knowledge is necessary for modelling fire suppression in countries such as Greece where direct attack on the flames using water provided by fire trucks is the main ground firefighting method. The study presented here is an experimental effort to identify some of the key factors affecting the hose laying rate and to establish some initial values for commonly encountered situations in Greece.

Data were collected by building hose lays in Aleppo pine (Pinus halepensis) forests with shrub understory on mount Hymettus near Athens, Greece. The hose lays were built by professional firefighters on forest roads or trails that did not hinder their movement. The parameters that were varied were a) Number of firefighters (FF); there were 2 or 3 firefighters laying hose in addition to the driver, as is usually the case with firetrucks in Greece b) Site slope (\%) (SLOPE); it varied between -28 and 27\%, and c) Length of hose lay (LENGTH); three lengths were selected: 100, 200, and $300 \mathrm{~m}$. The trials were timed with a chronometer and a hose laying rate (HLR) was calculated. Multiple linear regression analysis of the data resulted in the following equation:

HLR $=1.028-0.003 *$ LENGTH $+0.477 *$ FF $-0.024 *$ ABS_SLOPE

Where (ABS_SLOPE) is the absolute value of SLOPE and FF is the number of firefighters. The value of the equation, its limitations and its potential uses are discussed in relation to the approaches taken in other studies on fireline production rates.
\end{abstract}

Keywords: forest firefighting, hose laying rate, Greece

\section{Introduction}

In forest fire management, decisions on presuppression planning, dispatching of firefighting forces and operational planning of fire suppression require knowledge of the productivity, the effectiveness and the limitations of the aerial and ground resources (Xanthopoulos 2002). Numerous studies have examined and tried to model the firefighting process (Fried and Fried 1996, Fried et al. 2006), building on other studies that examined, for example, fireline production rates with bulldozers and hand crews (Broyles 2011), length of fire front extinguished by water and retardant drops from various types of aerial resources, etc. All such information has to be interpreted carefully because it can be affected by various local factors (Fried and Gilless 1989, Hirsch and Martell 1996). The same is true for the development and use of firefighting models.

One example of limited reliable information in regard to firefighting performance has to do with use of water under pressure and the related production rates. The studies focusing on this subject, either based on in-field measurements or on expert opinion, are relatively few and the results are very variable (Parker et al. 2007). This variability is the result of the multitude of influencing factors such terrain, wind speed, flame height and fuel type. It might be possible to reduce this variability if the effect of 
various factors is first measured separately and then the effects are combined. For example, in regard to water based ground firefighting, it might be possible to examine the rate of hose laying by ground forces trying to reach and follow the head or flanks of a fire, before considering the difficulty of extinguishment posed by the variation in flame length.

The study presented here is an experimental effort to identify some of the key factors affecting the hose laying rate (HLR) and to establish some initial values for commonly encountered situations in Greece. This subject has received relatively limited attention globally and there is no specific knowledge for Greek conditions. Such knowledge is necessary for modelling fire suppression in countries such as Greece where direct attack on the flames using water provided by fire trucks is the main ground firefighting method.

\section{Methods}

Data were collected by building hose lays in Aleppo pine (Pinus halepensis) forests with shrub understory on mount Hymettus near Athens, Greece. The hose lays were built by professional firefighters on forest roads or trails without vegetation that would hinder their movement. The hose used for all tests was of the type most commonly used for forest firefighting by the Fire Service in Greece: $2.5 \mathrm{~cm}$ (1 inch) in diameter adhering to the standard PR EN 1924-1, in lengths of 25 meters with Storz type couplings. The parameters that were varied were:

- Number of firefighters (FF). There were 2 or 3 firefighters laying hose in addition to the driver, as is usually the case with firetruck crews in Greece.

- Slope (SLOPE). It varied between -28 and $+27 \%$.

- Length of hose lay (LENGTH). Three lengths were selected: 100, 200 and $300 \mathrm{~m}$.

The experiments took place between June and November 2012. Weather conditions, namely air temperature, relative humidity, wind speed, sunshine or cloudy conditions, were recorded for each trial. The aim was to check for probable influence of these factors in the performance of the firefighters. The trials were timed with a chronometer and a hose laying rate (HLR) was calculated by dividing the length by the time $(\mathrm{m} / \mathrm{s})$. A total of 24 trials were performed (Figure 1$)$.

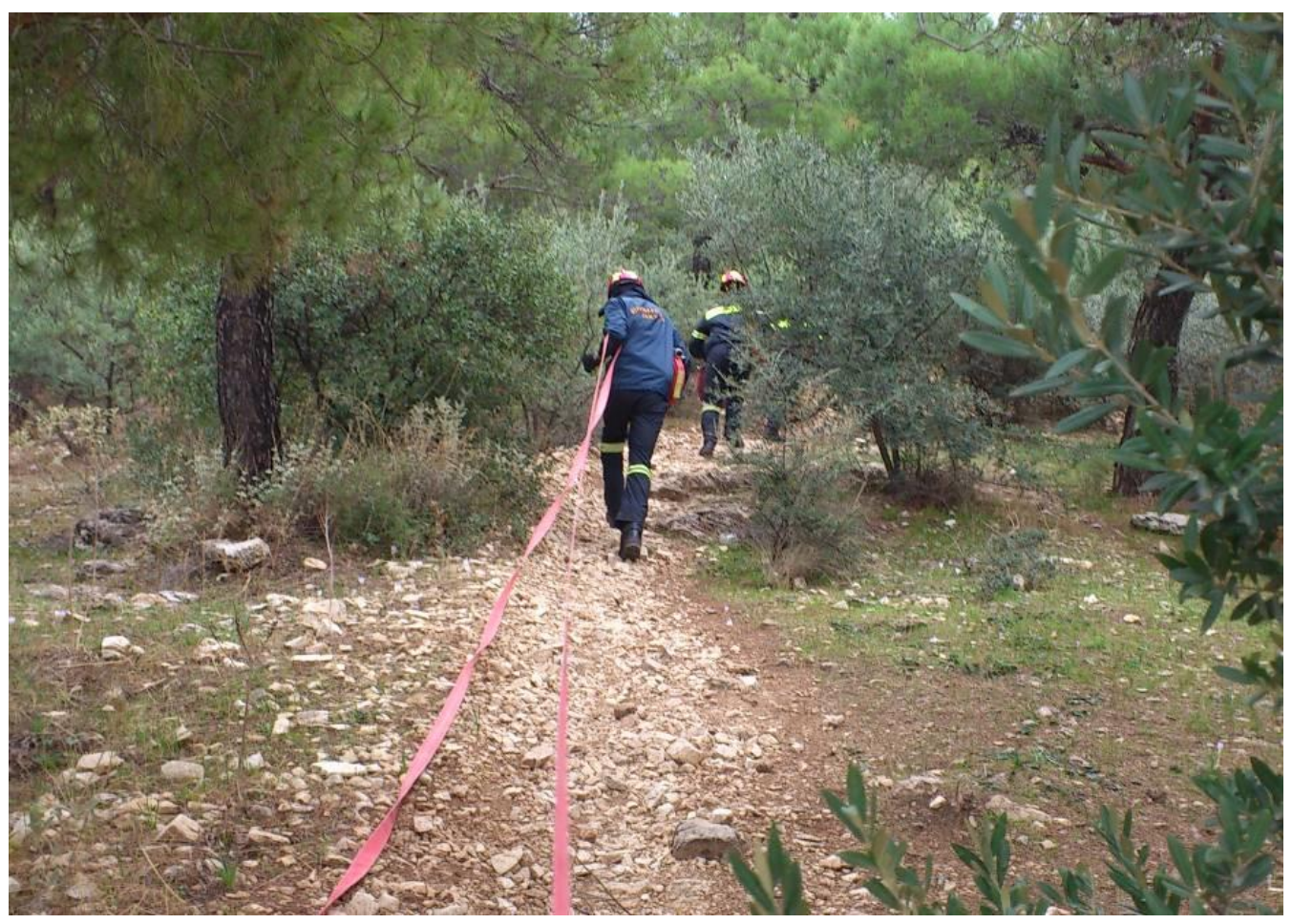

Figure 1. A photo of one of the hose laying trials

Advances in Forest Fire Research - Page 1412 


\section{Analysis and results}

The data were analyzed using the SPSS statistical software. The descriptive statistics of the data set are shown in Table 1. HLR varied between 0.7 and $2.44 \mathrm{~m} / \mathrm{s}(2.052$ to $8.784 \mathrm{~km} / \mathrm{h})$. The highest HLR was achieved by 3 firefighters creating a $100 \mathrm{~m}$ long hose lay downslope, on a 14\% slope.

Table 1. Descriptive statistics of the 24 record data set.

\begin{tabular}{|l|c|c|r|r|c|}
\hline Parameter & $\mathrm{N}$ & Minimum & Maximum & Mean & Std. Deviation \\
\hline Temperature $\left({ }^{\circ} \mathrm{C}\right)$ & 24 & 15.0 & 32.0 & 22.79 & 5.2670 \\
\hline Relative humidity $(\%)$ & 24 & 24.0 & 75.0 & 59.79 & 18.2350 \\
\hline Wind speed $(\mathrm{km} / \mathrm{h})$ & 24 & 1.9 & 27.8 & 10.500 & 5.7424 \\
\hline Number of firefighters (FF) & 24 & 2.0 & 3.0 & 2.50 & 0.5110 \\
\hline SLOPE $(\%)$ & 24 & -28.0 & 27.0 & 1.125 & 17.7462 \\
\hline LENGTH (m) & 24 & 100.0 & 300.0 & 175.00 & 84.6990 \\
\hline HLR (m/s) & 24 & 0.57 & 2.44 & 1.3041 & 0.52909 \\
\hline
\end{tabular}

Multiple linear regression analysis using the stepwise procedure excluded the weather parameters from the list of selected independent variables. As steep slope may impede efforts both upslope and downslope a derived variable ABS_SLOPE, equal to the absolute value of SLOPE, was calculated and tried. The model developed is:

$$
\text { HLR }=1.028-0.003 * \text { LENGTH }+0.477 * \text { FF }-0.024 * \text { ABS_SLOPE }
$$

The multiple regression equation has a $p$-value $<0.001$ and an adjusted $R^{2}=0.641$. The constant of the equation has a $\mathrm{p}$-value $=0.013$. All the coefficients of the variables are statistically significant at the 0.005 level.

The effect of slope was investigated further by plotting SLOPE against HLR for the laying of $100 \mathrm{~m}$ of hose by two firefighters (six measurements) and by three firefighters (six more measurements). The data points and the polynomial lines capturing the trends are shown in figure 2 . As seen, HLR increases for downslope hose laying on gentle slope, up to approximately $10 \%$, but then drops as a steeper slope makes downslope firefighter movement more difficult.

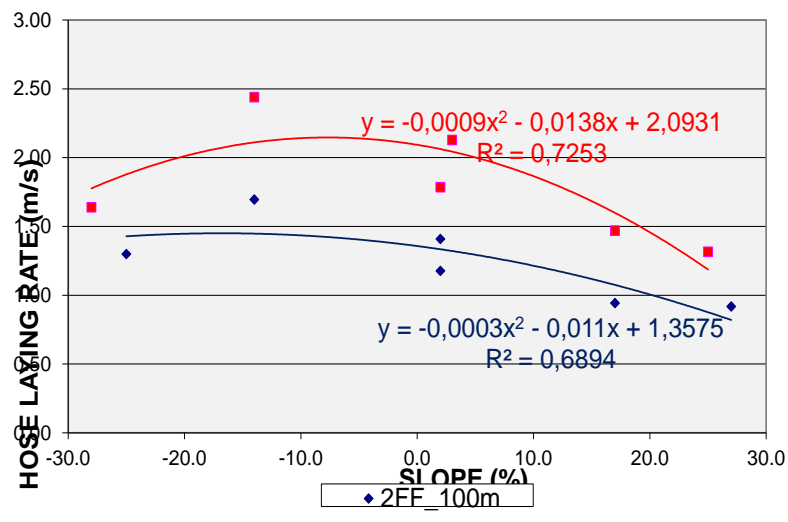

Figure 2. The effect of SLOPE on HLR for hose laying tests of $100 \mathrm{~m}$ LENGTH by two or three firefighters. 


\section{Discussion and conclusions}

The equation developed identified three of the important variables affecting HLR and can be useful in ground fire fighting modelling in Greece, namely number of firefighters, length of hose lay and slope. The lack of influence of weather conditions can be explained by the lack of extreme conditions at the time of the tests and the short duration of each trial which does not allow fatigue to build-up. These conditions may be important if firefighting continues for hours.

The equation can be used for quick calculations either in the form of a table or of a graph (figure 3 ). It is recognized that it has limitations due to the small sample size, the limited range of values of the variables and the omission of certain other influencing factors such as building hose lay in thick vegetation that impedes movement of the firefighters. The most important weakness is that it does not account for the increase in HLR when hose is laid downslope on slopes less than about $15 \%$. A larger data set would be needed in order to establish with confidence the exact slope threshold beyond which negative slope reduces HLR. If using the equation for estimating HLR for laying hose on negative slopes (downslope) in the range 5-15\%, for example in a computer based model for fire suppression, it is suggested to use the HLR estimated for $0 \%$ slope increased by $10 \%$ in order to reduce error.

The HLR values calculated by equation (1) should be considered as optimum. Such performance can be expected realistically by non-fatigued initial attack firefighter crews arriving to a fire. Future work on the subject is expected to provide additional data and to even allow examination of a non-linear influence of the independent variables on HLR outside the range of values tested so far.

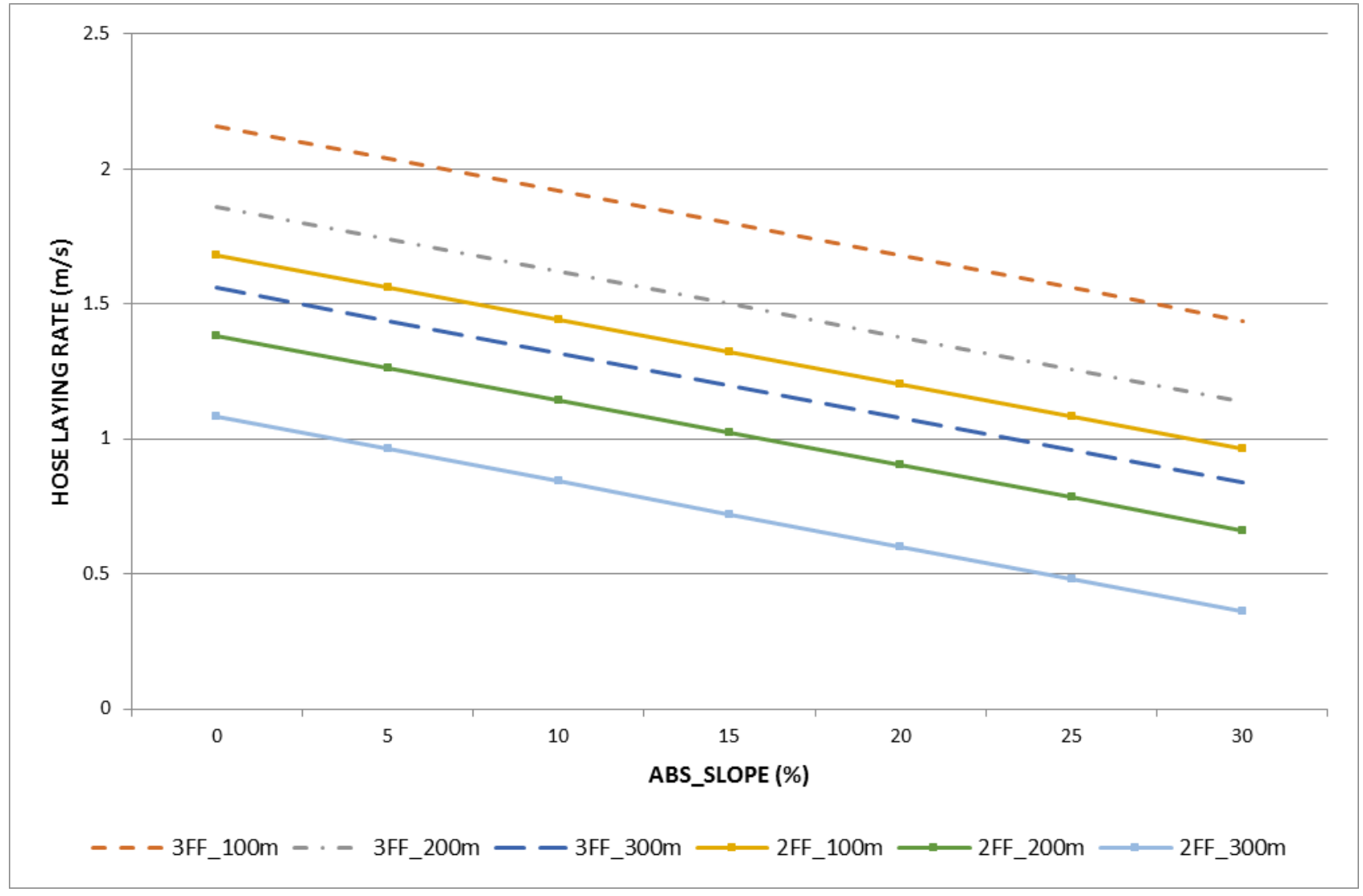

Figure 3. HLR vs ABS_SLOPE according to equation (1), for teams of 2 and 3 firefighters and hose lay lengths of 100, 200 and $300 \mathrm{~m}$. 
As a final note, it should be mentioned that the HLR values reported here are not comparable with the values reported in studies such as those of Fried and Gilless (1989) or reviewed by Parker et al. (2007) because they do not include fire extinguishment of any short as is the case in those studies. Thus, they can be used, for example, when trying to estimate the time required for reaching a fire front or flanking with hose. Then, the fireline production rates with engine hose lay depending on the type of vegetation (as for example reported in Table 1 of Fried and Gilless (1989)) can be used.

\section{Acknowledgements}

The research reported here is part of the work of the second author for a M.Sc. degree at the National and Kapodistrian University of Athens. The first author participated in the frame of a project of the Institute of Mediterranean Forest Ecosystems and Forest Products Technology (IMFE\&FPT) titled "Contribution to Fire Prevention in 2013-2014 using the INCA methodology". The project was funded by the Special Secretariat for Forests through the "Green Fund" of the Greek Ministry of Environment, Energy, and Climate Change.

\section{References}

Broyles G (2011) Fireline production rates. San Dimas, CA: US Department of Agriculture, Forest Service, San Dimas Technology and Development Center. 5100—Fire Management 11511805 P.

Parker R, Ashby L, Pearce G, Riley D (2007) Review of methods and data on rural fire suppression resource productivity and effectiveness. Ensis Forest Biosecurity and Protection, Scion, Rotorua, New Zealand.

Fried JS, Gilless JK (1989) Expert Opinion Estimation of Fireline Production Rates. Forest Science 35(3), 870-877.

Fried JS, Fried BD (1996) Simulating wildfire containment with realistic tactics. Forest Science 42(3), 267-281.

Fried JS, Gilless JK, Spero J (2006) Analysing initial attack on wildland fires using stochastic simulation. International Journal of Wildland Fire 15(1), 137-146.

Hirsch KG, Martell DL (1996) A review of initial attack fire crew productivity and effectiveness. International Journal of Wildland Fire 6, 199-215.

Xanthopoulos G (2002) The DISPATCH program for the dispatching of Canadair CL-215 and fire trucks in Greece. In proceedings of the International Workshop on "Improving Dispatching for Forest Fire Control". December 6-8, 2001. Chania, Crete, Greece. Ed. G Xanthopoulos) pp. 133 141. (Mediterranean Agronomic Institute of Chania, Chania, Crete, Greece) 